\title{
Pendampingan Masyarakat dalam Budidaya Rumput Laut di Kepulauan Sapeken Kabupaten Sumenep Jawa Timur
}

\author{
Nurwidodo ${ }^{1 *}$, Abdulkadir Rahardjanto ${ }^{2}$, Husamah ${ }^{3}$, Mas'odi $^{4}$ \\ 1,2,3Pendidikan Biologi, Fakultas Keguruan dan Ilmu Pendidikan, dan PSLK Universitas Muhammadiyah Malang \\ 4 Sekolah Tinggi Keguruan dan Ilmu Pendidikan (STKIP) PGRI Sumenep
}

\author{
A R T I C L E I N F O \\ Article history: \\ Received 15 March 2018 \\ Received in revised form \\ 10 May 2018 \\ Accepted 30 June2018 \\ Available online 22 August \\ 2018

\section{Kata Kunci:} \\ Budidaya rumpu laut, \\ pendampingan masyarakat, \\ Sapeken \\ Keywords: \\ Seaweed cultivation, \\ community advocation, \\ Sapeken
}

\begin{abstract}
A B S T R A K
Budidaya rumput laut di Kepulauan Sapeken Kabupaten Sumenep sangat potensial untu dilakukan, namun pada kenyataannya para nelayan/petani masih mengalami banyak kendala, sehingga aktivitas tersebut belum memiliki kontribusi bagi peningkatan kesejahteraan masyarakat. Tim telah melakukan kegiatan pengabdian di Kepulauan Sapeken Kabupaten Sumenep, sehingga artikel ini bertujuan mendeskripsikan implementasi pendampingan masyarakat dalam budidaya rumput laut di daerah tersebut. Subjek dalam pengabdian adalah 2 kelompok tani rumput laut (masing-masing terdiri atas 10 orang pembudidaya). Kegiatan pengabdian ini dilaksanakan selama delapan bulan. Metode yang digunakan dalam pengabdian ini adalah survey, demonstrasi, dan praktek langusng, dan evaluasi. Keterlaksanaan atau keberhasilan pengabdian didasarkan pada terpenuhinya indikator-indikator proses pengabdian dan produk yang dihasilkan dalam pengabdian, Kegiatan pengabdian dievaluasi dalam hal proses dan akhir kegiatan. Kegiatan pengabdian dianggap telah berhasil bila persentase keterlibatan dan keaktifan masyarakat mencapai $\geq 75 \%$, masyarakat mampu melakukan budidaya. Hasil evaluasi menunjukkan bahwa masyarakat mitra sangat antusias terlibat, $100 \%$ terlibat dalam budidaya, da nada peningkatan produksi budidaya rumput laut. Dapat disimpulkan bahwa pengabdian masyarakat telah diimplementasikan sesuai dengan rencana.
\end{abstract}

Seaweed cultivation in Sapeken Islands of Sumenep Regency, is very potential to be done, but in reality the cultivator are still experiencing many obstacles, so the activity has not yet contributed to the improvement of people's welfare. The team has been carrying out activities of devotion in the Sapeken Islands of Sumenep Regency, so this article aims to describe the implementation of community assistance in seaweed cultivation in the area. Subjects in service are 2 groups of seaweed cultivator (each consisting of 10 farmers). This devotional activity is held for eight months. The methods used in this devotion are surveys, demonstrations, and direct practice, and evaluation. The performance or success of the service is based on the fulfillment of the indicators of the process of service and the product resulting in devotion. Devotional activities are evaluated in terms of process and end of activity. Devotional activities are considered successful when the percentage of community involvement and activeness reaches $\geq 75 \%$, the community is able to cultivate. Evaluation results show that the partner community is enthusiastically involved, $100 \%$ involved in cultivation, and increase the production of seaweed cultivation. It can be concluded that community service has been implemented in accordance with the plan.

Copyright () Universitas Pendidikan Ganesha. All rights reserved.

\footnotetext{
${ }^{*}$ Corresponding author.

E-mail addresses: nurwidodo@umm.ac.id (Nurwidodo), rahardjanto@gmail.com (Abdulkadir Rahardjanto), usya_bio@umm.ac.id (Husamah), bangodi13@gmail.com
} 


\section{Pendahuluan}

Masyarakat pesisir atau kepulauan (nelayan, petani, atau pembudidaya) cenderung mengalami keterbelakangan secara ekonomi dan berbagai sektor lainnya. Mereka mengalami kemiskinan secara kultural dan juga secara struktural (Agussalim, 2014; Cristianawati, 2017). Kemiskinan dialami secara internal berupa pola pikir/mental/kesadaran dan eksternal berupa kebijakan pemerintah yang tidak berpihak (cenderung bersifat top down, menjadikan masyarakat sebagai obyek dan bukan subyek) ketidakadilan pasar, kerakusan pemilik modal/tengkulak, ketidakpedulian kaum intelektual, dan berbagai faktor di luar kendali masyarakat (Agussalim, 2014; Hamzah, 2015; LPPM-UNEJ, 2017; Surjanti \& Nuswantara, 2016; Sutrisno, 2012). Rendahnya produktivitas, rendahnya daya saing, terbatasnya saranaprasarana, keterbatasan akses ke pasar dan informasi pasar, rendahnya pemahaman terkait nilai tambah (value added) dan lemahnya akses permodalan juga menjadi masalah berkepanjangan petani sehingga kesejahteraan masih jauh dari harapan (Bappenas, 2016; Izzaturrahim, Waluti, Rahayuwati, \& Darmadji, 2015; JICA, 2011; KIARA, 2015; Masyhuri, 2013; Prakoso, 2013; Rosni, 2017; Wardhani, Rekyani, \& Indayati, 2010). Mereka juga mengalami keterbelakangan pendidikan. DATA Survei Sosial Ekonomi Nasional 2013 menunjukkan bahwa 70\% nelayan yang telah menempuh pendidikan dasar, dan hanya sekitar 1,3\% yang berpendidikan tinggi (DPR RI, 2014).

Permasalahan masyarakat tersebut membutuhkan perhatian berbagai pihak untuk menyelesaikannya. Sebab bagaimanapun, masyarakat pesisir dan kepulauan adalah pihak yang memiliki sumbangan terpenting bagi tersedianya produk kelautan dan perikanan, untuk memenuhi konsumsi masyarakat umum ataupun kebutuhan berbagai industri pengolahan (DPR RI, 2014). Sektor perikanan berperan besar dalam penguatan ekonomi nasional, khususnya menyediakan lapangan kerja yang bersidat padat karya, sumber penghasilan nelayan, memberikan impuls dalam mendukung ketahanan pangan, sumber protein hewani bagi masyarakat luas, dan pada akhirnya menjadi sumber devisa bagi Negara (Huseini, 2007; Nahruddin, 2014). Nelayan, petani, maupun pembudidaya adalah kelompok sosial yang terkait langsung dengan pemanfaatan sumber daya pesisir dan kelautan (Hapsati \& Fuad, 2017; Rahmatullah, 2016). Potensi pesisir, pantai, dan laut perlu dimanfaatkan dan dikelola secara bijak sehingga mampu memberikan kesejahteraan bagi masyarakat setempat. Prinsip sustainability (keberlanjutan) perlu ditekankan agar aktivitas mata pencaharian tidak menimbulkan kerusakan bagi lingkungan (Khodijah \& Raza'i, 2014; Novianti, 2017). Selain itu, kegiatan nelayan yang mengarah kepada eksploitasi perlu diarahkan kepada pola budidaya. Namun demikian, karena kegiatan budidaya sangat membutuhkan ketekunan, kesabaran, dan konsistensi maka pendampingan untuk mengubah pola pikir juga harus dilakukan (Firdaus, Indriana, Dwiono, \& Munandar, 2017).

Kegiatan pendampingan, pelatihan, atau pemberdayaan pada sektor ekonomi perlu diupayakan karena merupakan penopang penting bagi kehidupan masyarakat dengan berdasarkan pada potensi wilayah sekitar (Agustin, Sulestiani, \& Widihartanti, 2015; Anonim, 2015b; Ibad, 2017; Triadiyatma, 2016), yang bermanfaat untuk 1) Meningkatkan pendapatan dan kesejahteraan masyarakat (Anonim, 2015a; Ishak \& Siang, 2013); 2) Menciptakan lapangan kerja baru yang mampu menyerap tenaga kerja yang luas; 3) Mendorong jiwa kooperatif dan kerjasama serta jaringan; 4) Membantu kegiatan promosi hasil usaha melalui berbagai media; dan 5) Membantu sarana, prasarana, dan modal usaha yang akan sangat bermanfaat bagi mereka untuk mulai membuka usaha, sehingga terjebak rentenir (Adnyani, Sukerti, \& Wisnawa, 2014; Imaniar, 2017; Laksamana, Ro'is, Syahputra, Firdausiyah, \& Reswita, 2017; Nurfadilah, 2016). Pengabdian diharapkan memiliki dampak dalam hal product knowledge, yaitu menambah pengetahuan tentang segala aspek fisik yang dapat dilihat dan dirasakan, manfaat fisik berupa peningkatan kualitas produk, manfaat psikologis berupa dampak sosial ketika berinteraksi, dan nilai-nilai yang diperoleh ketika berinteraksi (Farid, Wulanditya, \& Puspitaningrum, 2016; Hindradjit, Rianto, \& Arieffiani, 2017).

Sehubungan dengan itu, melalui dana skim IbW-CSR Kemenristek Dikti dan bermitra dengan Kangean Energy Indonesia, kami mengadakan kegiatan pengabdian masyarakat di Kepulauan Sapeken Kabupaten Sumenep, Jawa Timur. Sasaran pengabdian ini adalah nelayan yang juga sebagai petani/pembudidaya rumput laut. Kepulauan Sapeken merupakan kepulauan di Kabupaten Sumenep dimana sebagian besar masyarakatnya bermata pencaharian sebagai nelayan atau menggantungkan hidupnya pada sumberdaya berbasis laut Kepulauan Sapeken memiliki potensi besar dalam hal budidaya rumput laut. Hal ini berdasarkan tinjau potensi rona lingkungan dan hidrodinamika laut, potensi sumberdaya manusia, dan potensi berdasarkan sifat budidaya rumput laut (Nurwidodo Nurwidodo, Rahardjanto, Husamah, Mas'odi, \& Mufrihah, 2017). Sejak 2008 di di Kepulauan Sapeken ditemukan banyak masyarakat yang menjadi pembudidaya rumput laut. Akan tetapi, dalam perkembangannya pada 5 tahun terakhir sangat jarang ditemukan adanya pembudidaya rumput laut. Pembudidayaan rumput laut hanya terdapat di Pulau Sadulang Besar, Pulau Sepanjang, dan Pulau Sasiil, namun dalam bentuk usaha 
keluarga yang sederhana (ala-kadarnya), tanpa sentuhan teknologi dan pengetahuan yang memadai ( $\mathrm{N}$. Nurwidodo, Rahardjanto, Husamah, \& Mas'odi, 2017). Pola budidaya seperti ini tentunya menjadi alasan mengapa budidaya rumput laut tidak maksimal dalam mendorong kesejahteraan masyarakat setempat. Petani rumput laut sangat membutuhkan pendampingan agar aktivitas mereka dapat maksimal (Darmadi, Ayu, \& Semara, 2016; Nurholis, 2016). Rumput laut berpotensi meningkatkan kesejahteraan masyarakat karena merupakan salah satu komoditas ekspor dan tren permintaan pasar terus meningkat (Mutiara, Wibowotomo, Issutarti, \& Wahyuni, 2018; Setiawati \& Ilma, 2017; Wirakusuma, 2014). Permintaan pasar dunia ke Indonesia mencapai $21,8 \%$ pertahunnya. Pemenuhan untuk memasok permintaan tersebut hanya sekitar 13,1\%, sehingga dapat dikatakan bahwa potensi pasar terbuka lebar (Kresnarini, 2011).

Dalam perkembangannya diharapkan bahwa usaha yang didampingi berkontribusi menciptakan lapangan pekerjaan dan turut serta mengurangi angka kemiskinan. Usaha baru dapat membantu pertumbuhan ekonomi masyarakat, sehingga diharapkan mampu menjadi alternatif bagi masyarakat nelayan untuk tetap bertahan dan kuat menghadapi semua musim termasuk musim paceklik yang selama ini cenderung menambah beban hidup mereka (Rachmaningtyas, 2015; Rosyid, 2013). Pengabdian ini berorientasi pada pemberdayaan masyarakat. Pendekatan ini bermakna masyarakat berposisi sebagai pelaku dan penerima manfaat dari proses mencari solusi dan meraih hasil kegiatan. Pendekatan ini mensyaratkan dan mendorong terciptanya kemandirian masyarakat dalam mengatasi masalah yang dihadapi (Karsidi, 2002). Artikel ini bertujuan mendeskripsikan implementasi pendampingan masyarakat dalam budidaya rumput laut di Kecamatan Sapeken Kabupaten Sumenep Jawa Timur

\section{Metode}

Mitra kegiatan pengabdian ini adalah masyarakat nelayan (petani) rumput laut di Pulau Pagerungan Kecil dan Pulau Sadulang Besar, Kecamatan Sapeken, Kabupaten Sumenep, Jawa Timur. Subjek dalam pengabdian adalah 2 kelompok tani rumput laut (masing-masing terdiri atas 10 orang pembudidaya). Kegiatan pengabdian ini dilaksanakan selama delapan bula, dengan tahapan dan metode pelaksanaan seperti disajikan pada Tabel 1.

'Tabel 1. Metode Pelaksanaan Pengabdian Kecamatan Sapeken Sumenep

\begin{tabular}{|c|c|c|}
\hline & $\begin{array}{c}\text { Program/Kegiatan dan uraian langkah solusi atas persoalan } \\
\text { yang disepakati }\end{array}$ & Metode Pelaksanaan \\
\hline \multicolumn{3}{|c|}{$\begin{array}{l}\text { 1. Pengenalan dan Implementasi Paradigma Budidaya Rumput Laut } \\
\text { (kelompok kecil/petani model). }\end{array}$} \\
\hline & a) Pemetaan potensi lahan dan budidaya & a. Survey \\
\hline & b) Pemetaan aspek SDM masyarakat & b. Survey \\
\hline & $\begin{array}{l}\text { c) Sosialisasi program dengan pejabat terkait di kecamatan dan } \\
\text { desa }\end{array}$ & $\begin{array}{l}\text { c. Sosialisasi dan } \\
\text { demonstrasi }\end{array}$ \\
\hline & $\begin{array}{l}\text { d) Sosialisasi dan pelatihan serta penguatan kelembagaan } \\
\text { petani/nelayan dan kelompok masyarakat untuk mengubah } \\
\text { atau memperkuat paradigma dan semangat masyarakat terkait } \\
\text { budidaya rumput laut }\end{array}$ & $\begin{array}{l}\text { d. Sosialisasi, workshop, } \\
\text { praktek langsung }\end{array}$ \\
\hline \multicolumn{3}{|c|}{ e) Pelatihan paradigma baru budidaya rumput laut } \\
\hline & $\begin{array}{l}\text { f) Penyediaan sarana dan prasarana budidaya dan penyediaan } \\
\text { bibit. }\end{array}$ & $\begin{array}{l}\text { e. Workshop } \\
\text { f. Pengadaan }\end{array}$ \\
\hline & g) Budidaya rumput laut & g. Praktek langsung \\
\hline & $\begin{array}{l}\text { h) Pelatihan pengolahan dan pengemasan pasca panen (berbagai } \\
\text { hasil olahan rumput laut). }\end{array}$ & $\begin{array}{l}\text { budidaya } \\
\text { h. Pelatihan/ Workshop }\end{array}$ \\
\hline & $\begin{array}{l}\text { i) Pendampingan uji kandungan rumput laut Sapeken di } \\
\text { Laboratorium. }\end{array}$ & i. Pendampingan dan uji lab \\
\hline & $\begin{array}{l}\text { j) Pendampingan Penguatan Semangat Berbudidaya, Pengolahan } \\
\text { dan Pengemasan pasca panen, }\end{array}$ & $\begin{array}{l}\text { j. Pendampingan dan } \\
\text { pemberian motivasi }\end{array}$ \\
\hline & $\begin{array}{l}\text { Sosialisasi dan pencanangan gerakan sadar gizi pelajar kepulauan } \\
\text { berbasis sumberdaya laut dan hasil olahannya khususnya rumput } \\
\text { laut }\end{array}$ & $\begin{array}{l}\text { Praktek langsung oleh tim IbW } \\
\text { Praktek langsung oleh tim IbW } \\
\text { (analisis data, penulisan }\end{array}$ \\
\hline & $\begin{array}{l}\text { Pembuatan laporan kegiatan tahunan dan Publikasi Jurnal pada } \\
\text { tahun I }\end{array}$ & $\begin{array}{l}\text { artikel, pembuatan PPT, } \\
\text { submit makalah, dan } \\
\text { presentasi) }\end{array}$ \\
\hline
\end{tabular}


Instrumen atau alat dan bahan yang digunakan dalam pengabdian ini, yaitu berbagai materi presentasi, contoh produk, alat dokumentasi, buku catatan, dan instrument evaluasi. Berbagai alat (sarana) budidaya rumput laut dan alat penanganan pasca panen juga disiapkan atau disediaan. Mengingat bahwa budidaya rumput laut membutuhkan alat transportasi khusus, maka tim menyiapkan alat transportasi berupa sampan dan perahu bermesin.

Metode yang digunakan dalam pengabdian ini adalah survey, demonstrasi, dan praktek langsung, dan evaluasi. Data dikumpulkan dengan cara terlibat langsung dalam aktivitas masyarakat, pengambilan sampel produk, perekaman dokumen, dan penyebaran angket respon masyarakat mitra. Data yang dianalisis secara deskriptif.

Keterlaksanaan atau keberhasilan pengabdian didasarkan pada terpenuhinya indikator-indikator proses pengabdian dan produk yang dihasilkan dalam pengabdian, Kegiatan pengabdian dievaluasi dalam hal proses dan akhir kegiatan. Kegiatan pengabdian dianggap telah berhasil bila persentase keterlibatan dan keaktifan masyarakat mencapai $\geq 75 \%$, masyarakat mampu melakukan budidaya dengan hasil yang meningkat dibandingkan sebelum dilaksanakannya pengabdian, dan semua tahapan kegiatan yang telah direncakanan dapat terlaksana.

\section{Hasil dan pembahasan}

Kegiatan pengabdian yang telah dilaksanakan dan IPTEK yang diberikan kepada masyarakat adalah sebagai berikut:

\section{Koordinasi dan Konsolidasi}

Tim melakukan koordinasi dan konsolidasi internal untuk menyamakan persepsi antar tim pengabdian, merencanakan kegiatan yang akan dilakukan, dan melakukan pembagian tugas. Kegiatan ini terlaksana dengan baik (100\%). Hasil dan luaran kegiatan ini adalah kesepakatan, catatan/notulen kegiatan, dan presensi kegiatan. Tim juga melakukan koordinasi dengan perusahaan yang menjadi mitra yaitu Kangean Energy Indonesia (KEI ltd). Kegiatan ini dilaksanakan di Kantor KEI Perwakilan Surabaya. Kegiatan ini diikuti oleh 1 orang Ketua Tim Pengabdian, 2 orang anggota tim pengabdian, 1 orang Manager Representatif KEI perwakilan Surabaya, dan 2 orang staf bagian Community Development KEI perwakilan Surabaya. Kegiatan terlaksana dengan baik, dengan persentase 100\%. Kegiatan ini menghasilkan adanya kesamaan persepsi tentang kegiatan yang dilakukan bersama, kontribusi dan peran masing-masing, dan masukan dari KEI kepada tim berdasarkan pengalaman pemberdayaan masyarakat (khususnya terkait kultur masyarakat setempat). Hasil lain adalah catatan/notulen kegiatan, dan presensi kegiatan.

\section{Pemetaan/Kajian Potensi Budidaya dan Aspek Sumberdaya Manusia (SDM) Masyarakat}

Kegiatan dilaksanakan oleh Tim Pengabdian dengan mitra, dengan persentase keterlaksanaan sebesar 100\%. Kangean Energy Indonesia (KEI) telah memiliki dokumen hasil Pemetaan Sosial di Sekitar Wilayah Operasi Lapangan Gas Pagerungan, yang dilakukan oleh Departemen Sains Komunikasi dan Pengembangan Masyarakat Fakultas Ekologi Manusia IPB. Hasil kajian dan pemetaan tersebut adalah diperolehnya informasi penting, sebagai berikut:

a. Di Pagerungan Kecil pernah ada kegiatan budidaya rumput laut, bahkan sudah pernah ada kelembagaan (kelompok) yang melibatkan petani rumput laut dan pengumpul lokal dengan orientasi pemasaran sampai ke Sumenep. Akan tetapi prosesnya masih tradisional, artinya belum ada upaya penggunaan bibit unggul dan upaya pencegahan penyakit, sehingga ketika timbul penyakit yang menyebabkan panen gagal dan harga jual rumput laut jatuh, maka petani rumput laut yang ada terpaksa berhenti berbudidaya rumput laut. Sejak tahun 2012 hingga tahun 2016, sudah tidak ada lagi kegiatan budidaya rumput laut yang dilakukan oleh masyarakat Pagerungan Kecil, baik yang di daerah perairan pulau maupun di daerah budidaya yang potensial meski berjarak sedikit agak jauh dari Pagerungan Kecil.

b. Telah ada upaya pembudidayaan rumput laut di Pulau Sadulang Besar, meskipun dalam skala kecil. Kegiatan ini atas inisiasi Kangean Energy Indonesia. Belum ada kelompok tani, masyarakat masih bekerja sendiri-sendiri.

c. Masyarakat Pagerungan Kecil dan Sadulang Besar relatif terbuka dengan pendatang, atau ramah dengan orang baru. Hal ini diharapkan memudahkan tim pengabdian dalam memberikan pengetahuan baru atau memberikan penguatan dalam kegiatan budidaya berbasis kelautan.

d. Derasnya arusnya informasi menyebabkan adanya pergeseran pola hidup masyarakat ke arah konsumtif, tidak sabar menunggu hasil, dan akhirnya banyak yang menggunakan cara-cara yang tidak 
ramah lingkungan. Misalnya, menggunakan potassium untuk menangkap ikan, merusak terumbu karang, dan menggunakan cara tidak sehat dalam berbisnis (melakukan perang harga).

e. Adanya budaya ikut-ikutan. Hal dapat bermakna positif dan negatif. Ada kecenderungan masyarakat di kepulauan, terutama di Pagerungan Kecil, dimana masyarakat kurang memiliki inisiatif dalam melakukan usaha karena ketakutan akan gagal. Namun, apabila mereka sudah melihat contoh warga masyarakat yang penghasilannya meningkat maka masyarakat akan ikut-ikutan mengembangkan usaha dan kegiatan yang sama. Sayangnya, karena hanya ikut-ikutan dan tanpa perencanaan yang baik maka banyak yang akhirnya gagal dan bahkan terjerat utang.

\section{Sosialisasi program dengan pejabat terkait (desa dan dusun)}

Untuk menyamakan persepsi dan mensosialisasikan kegiatan pengabdian yang dilakukan, tim melakukan pertemuan (bertamu) ke rumah aparat desa. Kegiatan ini juga dihadiri oleh Kepala Dusun Korma, perwailan kelompok tani, dan tokoh masyarakat. Pihak desa menyampaikan rasa terima kasih dan menyambut baik kegiatan ini dan berharap memiliki dampak positif bagi warga Pagerungan Kecil serta dapat menjadi contoh. Program ini diharapkan terus terlaksana dan dalam skala yang lebih luas. Pada kesempatan ini tim juga memberikan sumbangan ke kas desa untuk pembangunan, sesuai dengan peraturan desa.

\section{Sosialisasi, Pelatihan, dan Sarana dan Prasarana Budidaya, Penyediaan Bibit, dan Pelaksanaan Budidaya Rumput Laut}

Kegiatan sosialisasi dilaksanakan selama satu hari penuh, namun demikian persiapan dilakukan sejak seminggu sebelumnya. Kegiatan yang dilakukan adalah sosialisasi dan pelatihan serta penguatan kelembagaan petani/nelayan dan kelompok masyarakat untuk mengubah atau memperkuat paradigma dan semangat masyarakat terkait budidaya rumput laut (Pelatihan paradigma baru budidaya rumput laut). Kegiatan ini diikuti oleh angota kelompok yang telah menjadi mitra serta masyarakat Dusun Korma Desa Pagerungan Kecil Kecamatan Sapeken Kabupaten Sumenep.

Tim melakukan koordinasi dengan ketua kelompok petani yang menjadi mitra, yaitu Bapak Husni Mubarak. Kelompok ini diharapkan menjadi pilot project warga Pagerungan Kecil yang memulai budidaya rumput laut. Kelompok ini terdiri dari 10 orang. Diharapkan budidaya ini menjadi alternatif kegiatan produktif para nelayan apabila tidak melaut, sehingga mereka tetap memiliki tambahan penghasilan. Modal yang diberikan adalah Rp. 20.000.000. Dana tersebut digunakan untuk pembelian bibit, membeli tali (long line), tali pengikat bibit, pelampung, patok kayu, alat penjemuran, sewa perahu dan sampan, operasional sehari-hari, ongkos/upah tenaga pengikat bibit dan penanaman/pemasangan bibit di lokasi tanam, upah pemanenan, pembersihan tali, dan lain sebagainya.

Kegiatan persiapan budidaya dilakukan selama 15 hari, mulai dari pembelian segala peralatan, pembelian bibit, pencarian lokasi yang tepat, dan belajar teknik bertanam yang baik kepada pembudidaya yang telah berhasil di Pulau Sadulang Besar. Selanjutnya dilakukan kegiatan pembudidayaan. Berdasarkan informasi dari kelompok petani diketahui bahwa hingga akhir bulan Juli, mereka telah melakukan panen sebanyak 3 kali, dimana proses budidaya mulai dari penanaman adalah 45-50 hari. Pada pembudidayaan awal (pertama), karena keterbatasan bibit yang tersedia di pembudidaya lain, mereka hanya mampu menanam sebanyak 56 line dengan total berat bibit adalah 1.433 kilogram. Selanjutnya setelah memperoleh bibit, dilakukan penanaman kedua sebanyak 46 line dengan total bibit sebanyak 1519 kilogram. Pada pemanenan pertama didapatkan hasil berat basah $4.055 \mathrm{~kg}$. Hasil panenan tersebut sebagian digunakan sebagai bibit untuk pembudidayaan berikutnya. Sayangnya, pada saat umur rumput laut 30 hari, terjadi musibah berupa adanya badai/angin kencang dan ombak yang menyebabkan robohnya tiang pancang, putusnya tali (line) dan rontoknya rumput laut. Hal ini menyebabkan hasil panen hanya $\pm 2.000 \mathrm{~kg}$. Rumput laut yang masih tersisa sebagian digunakan untuk bibit. Pada pembudidayaan ketiga telah digunakan 90 line. Rumput laut yang berhasil dipanen mencapai 6000 kilogram (6 ton). Berdasarkan informasi yang diberikan, kelompok petani mendapatkan penghasilan kasar sebesar 4 juta rupiah, dimana selanjutnya digunakan sebagai operasional berikutnya, dan sisanya dijadikan kas. Saat ini, rumput laut yang dibudidayakan telah berumur 20 hari, berjumlah 90 line. Namun demikian, kendala yang dihadapi adalah cuaca yang tidak menentu, terkadang ada badai, dan turunnya harga penjualan rumput laut basah yang hanya seharga 600 rupiah per kilogram.

\section{Observasi ke Daerah Budidaya}

Daerah yang menjadi tempat budidaya adalah di kawasan Dusun Lekok Pulau Sepanjang. Membutuhkan perjalanan 1 jam dari pulau Pagerungan Kecil menggunakan perahu ketinting. Berdasarkan hasil observasi terlihat bahwa budidaya telah berjalan. Bahkan kelompok telah membangun semacam gubuk di atas laut/air khas suku Bajo. Tim juga ikut melakukan pemeriksaan tali (line) satu persatu, 
membersihkan ganggang dan hewan pengganggu, memasang pelampung, dan membenahi tali yang putus. Di gubuk juga terlihat tempat penjemuran rumput laut dan peralartan budidaya.

\section{Pendampingan Penguatan Semangat Budidaya}

Hasil panen yang diperoleh kelompok petani masih belum maksimal diakibatkan budidaya masih dalam tahap perintisan. Selain itu, kondisi cuaca yang tidak menentu serta adanya ancaman badai menyebabkan kegagalan panen. Rendahnya harga jual basah dan kering ikut menjadi hambatan dalam pembudidayaan rumput laut. Berbagai permasalahan yang dihadapi tersebut menyebabkan mulai menurunnya semangat petani. Oleh karena itu pendampingan, pemantauan secara berkala dan komunikasi yang terus berlanjut akan terus dilakukan.

Tim mengundang mitra/petani untuk mencari pengalaman baru di Malang, kunjungan ke laboratorium dimana hasil-hasil atau produk penelitian dosen-dosen UMM terkait rumput laut tersedia. Tim juga memberikan masukan, bersama-sama mencari jalan keluar, dan memotivasi mereka untuk tetap semangat dalam bertani/membudidayakan rumput laut. Tim juga berupaya menghubungkan mereka dengan beberapa "bos" atau "pembeli" rumput laut di Madura sehingga petani lebih memiliki alternative atau pilihan dalam menjual hasil panen dan dapat membandingkan harga. Kegiatan ini juga diikuti oleh para pelajar dan mahasiswa asal kepulauan Sapeken sehingga mereka dapat memberikan masukan dan saran, serta bersama-sama memecahkan masalah yang dihadapi.

Tim pengabdian juga telah membantu mitra/petani untuk melakukan uji kandungan lemak, protein, air, abu, dan karbohidrat untuk sampel rumput laut basah dan kering. Hasil pengujian seperti di Tabel 2.

Tabel 2. Hasil pengujian kandungan rumput laut Kepulauan Sapeken

\begin{tabular}{lllllll}
\hline Sampel & Ulangan & Lemak (\%) & Protein (\%) & Air (\%) & Abu (\%) & Karbohidrat (\%) \\
\hline \multirow{2}{*}{ Basah } & 1 & 2,315 & 1,734 & 59,390 & 13,410 & 23,150 \\
& 2 & 3,115 & 1,143 & 52,895 & 12,604 & 30,243 \\
\multirow{2}{*}{ Kering } & 1 & 4,689 & 3,23 & 38,870 & 20,908 & 31,709 \\
& 2 & 5,742 & 3,808 & 35,246 & 19,202 & 36,002 \\
\hline
\end{tabular}

Sosialisasi dan pencanangan gerakan sadar gizi pelajar kepulauan berbasis sumberdaya laut dan hasil olahannya khususnya rumput laut

Tim telah melakukan kegiatan sosialisasi dan pencanangan gerakan sadar giri pelajar kepulauan berbasis sumberdaya laut. Kegiatan dilaksanakan di SDN Negeri III Pagerungan Kecil Kecamatan Sapeken Kabupaten Sumenep. Sekolah ini berlokasi dekat dengan pantai ( \pm 100 meter) sehingga sangat strategis untuk menjadi tempat (mitra) kegiatan pengabdian dan pengembangan. Kegiatan ini diikuti oleh para siswa, wakil kepala sekolah (juga mewakili Ibu Kepala Sekolah), guru-guru, tokoh masyarakat, dan perwakilan orang tua (total berjumlah 51 orang). Mengingat kegiatan dilaksanakan bertepatan dengan bulan puasa maka kegiatan dikemas juga dengan buka puasa bersama peserta kegiatan.

Pada kesempatan ini, wakil kepala SDN Pagerungan Kecil III, menyambut baik dan merasa terharu karena kegiatan ini merupakan kegiatan pertama sekolah dengan perguruan tinggi, bahkan sejak sekolah ini berdiri tahun 90-an. Kegiatan ini akan memberikan dampak dalam memberikan pengetahuan, semangat, dan inspirasi bagi para siswa, guru, dan bahkan orang tua terutama terkait dengan kesadaran akan gizi. Bapak Wakil Kepala Sekolah mengungkapkan bahwa para siswa di sekolah ini kebanyakan berasal dari keluarga tidak mampu. Orang tua mereka adalah nelayan tradisional, dimana penghasilannya tergantung musim. Penyadaran dan penambahan pengetahuan bahwa sumber gizi yang baik dan menyehatkan justru ada di lingkungan atau di alam yang dekat dengan kehidupan sehari-hari, misalnya dalam hal ini di pantai dan laut, tentu akan berdampak sangat baik kepada siswa. Mengingat ini adalah upaya penyadaran secara dini, maka tentu ini akan menjadi bekal saat ini sampai mereka tua nanti.

Materi yang disampaikan oleh tim adalah terkait dengan pemenuhan gizi berbasis berbasis sumberdaya laut dan hasil olahannya khususnya rumput laut. Rumput laut adalah salah satu sumberdaya hayati yang terdapat di wilayah pesisir dan laut. Selain hidup bebas di alam, beberapa jenis rumput laut juga banyak dibudidayakan oleh sebagian masyarakat pesisir Indonesia, dan hal ini juga perlu dilakukan oleh masyarakat Pulau Pagerungan Kecil. Secara kimia rumput laut terdiri dari air $(27,8 \%)$, protein $(5,4 \%)$, karbohidrat $(33,3 \%)$, lemak $(8,6 \%)$ serat kasar $(3 \%)$ dan abu $(22,25 \%)$. Selain karbohidrat, protein, lemak dan serat, rumput laut juga mengandung enzim, asam nukleat, asam amino, vitamin (A,B,C,D, E dan K), serta mineral seperti nitrogen, oksigen, kalsium dan selenium serta mikro mineral seperti zat besi, magnesium dan natrium. Kandungan asam amino, vitamin dan mineral rumput laut mencapai 10-20 kali lipat dibandingkan dengan tanaman darat. 
Kegiatan pengabdian ini diawali dengan kegiatan koordinasi dan konsolidasi. Koordinasi dan konsolidasi perlu dilakukan untuk menyatukan pandangan terkait kegiatan yang akan dilaksanakan, peran dan tugas masing-masing serta memperoleh masukan berdasarkan pengalaman pemberdayaan masyarakat yang sejalan dengan budaya lokal atau setempat (Agustin et al., 2015; Nurwidodo Nurwidodo et al., 2017). Koordinasi dilakukan untuk menemukan bentuk pendampingan yang paling efektif an sesuai dengan kebutuhan mitra (Adnyani et al., 2014).

Tim pengabdian juga melakukan pemetaan/kajian potensi budidaya dan aspek sumberdaya manusia (SDM) masyarakat. Hasil kajian dan pemetaan tersebut berupa lima informasi penting. Inti dari informasi mengenai kondisi tersebut sejalan hasil kajian bahwa kecederungan kondisi petani rumput laut adalah pemanfaatan lahan cukup rendah dan partisipasi anggota relatif rendah Muara permasalah tersebut adalah aspek sosial dan teknis, yaitu pola pikir masyarakat yang cenderung ekstraktif, lebih nyaman mengeksploitasi dari pada membudidaya, serta faktor teknis lain seperti minimnya saranaprasarana pendukung (Firdaus et al., 2017). Pendapat tersebut sejalan pula dengan temuan serta pandangan dari berbagai peneliti atau pelaksana pengabdian (Agussalim, 2014; Bappenas, 2016; Hamzah, 2015; Izzaturrahim et al., 2015; LPPM-UNEJ, 2017; Masyhuri, 2013; Prakoso, 2013; Rosni, 2017; Surjanti \& Nuswantara, 2016; Sutrisno, 2012; Wardhani et al., 2010). Kegiatan pendampingan yang intensif menjadi solusi tepat untuk mengatasi permasalahan, sekaligus meningkatkan peluang keberhasilan program.

Selanjutnya tim telah melaksanakan kegiatan sosialisasi program dengan pejabat terkait (desa dan dusun). Kegiatan berikutnya adalah sosialisasi, pelatihan, dan sarana dan prasarana budidaya, penyediaan bibit, dan pelaksanaan budidaya rumput laut. Pendampingan Penguatan Semangat Budidaya juga dilakukan karena semangat merupakan faktor sangat penting dalam keberhasilan dan keseriusan masyarakat yang menjadi mitra. Kegiatan ini memberi dampak positif bagi keberlanjutan kegiatan karena tanpa adanya bantuan sarana, prasarana, modal, dan pendampingan maka masyarakat tidak akan memiliki kekuaata untuk bergerak dan berkembang. Kegiatan ini telah memberikan dampak, dimana hal yang sangat positif dari kegiatan ini adalah adanya pelibatan lebih banyak tenaga kerja, baik untuk mengikat rumput laut ke tali panjang, memasang tiang, dan memanen. Tenaga kerja khusus untuk menali dan memanen adalah ibu-ibu rumah tangga, sehingga akan membantu menambah penghasilan bagi keluarga. Kegiatan terlaksana dengan baik, dengan persentase sebesar 95\%.

Pendampingan yang intensif dan berkesinambungan harus terus dilakukan agar masyarakat terus memiliki semangat perubahan dan menjadi solusi bagi permasalahan yang bisa jadi mereka alami dalam proses usaha (Bappenas, 2016). Semangat berusaha yang sifatnya kolektif dari kelompok yang diberikan oleh pendamping sangat penting agar mereka secara produktif dan swadaya menjalankan program yang dirintis (Adnyani et al., 2014). Semangat yang kuat dan keinginan yang kuat untuk maju menjadi factor utama perubahan pada nelayan (Darmadi et al., 2016; Ishak \& Siang, 2013; Rosyid, 2013).

Untuk memastikan kualitas rumput laut sekaligus memberikan gambaran kepada pembudidaya mengenai rumput laut yang dibudidayaan. Rumput laut segar memiliki kandungan air sebesar 80-90\%, sedangkan kadar protein dan lemaknya relatif kecil. Meski demikian, susunan asam lemak yang ada pada rumput laut penting bagi kesehatan. Lemak rumput laut banyak mengandung omega-3 sertaomega- 6 . Omega-3 serta omega-6 adalah lemak penting bagi tubuh, khususnya dalam proses pembentukan membran jaringan otak, saraf, retina mata, plasma darah, dan organ reproduksi. Selain itu, kalori yang terkandung pada rumput laut cukup rendah. Dari total kandungan karbohidratnya, kurang dari seperempatnya yang dapat diserap tubuh, sehingga sangat baik untuk menjaga kesehatan tubuh (diet). Rumput laut pun kaya akan yodium, yaitu 2.400- 155.000 kali lebih banyak dibanding pada sayuran daratan (Kresnarini, 2011).

Kegiatan yang juga dilakukan dalam pengabdian ini adalah sosialisasi dan pencanangan gerakan sadar gizi pelajar kepulauan berbasis sumberdaya laut dan hasil olahannya khususnya rumput laut.Adanya mineral esensial diharapkan dapat meminimalisir angka defisiensi gizi terutama pada anak-anak di daerah terpencil. Bahan pangan berbasis rumput laut ini dapat diolah menjadi berbagai jenis hidangan baik berupa, kudapan (makanan kecil/kue), minuman, lauk pauk, sayur, maupun olahan lainnya melalui penerapan teknologi pengolahan pangan. Mengingat dewasa ini masyarakat mulai kembali peduli akan kesehatan dan kebutuhaan tubuh, maka hal ini harus juga dibudayakan dan menjadi kesadaran siswa, guru, dan para orang tua di SDN Pagerungan Kecil III. Peranan keluarga dan sekolah sebagai elemen masyarakat terkecil dalam masalah ini diharapkan menunjang tercapainya status kesehatan masyarakat secara maksimal serta terpenuhinya kebutuhan gizi melalui pemanfaatan bahan pangan berbasis rumput laut dalam konsumsi kesehariannya. Adanya kesadaran generasi muda terkait potensi laut di sekitar mereka menjadi hal yang sangat penting bagi kemajuan kehidupan masyarakat pesisir, nelayan, dan pembudidaya di masa yang akan datang (Cristianawati, 2017; Ibad, 2017). Apabila sumber daya manusia 
secara kuantitas dan kualitas terkelola dengan baik dan terarahkan maka dapat menjadi potensi besar untuk kemajuan dan pembangunan sektor kelautan, bahari, dan budidaya (Darmadi et al., 2016).

\section{Simpulan dan saran}

Kegiatan pengabdian IbW-CSR petani rumput laut berjalan dengan baik atau sesuai dengan target, yaitu pendampingan budidaya rumput laut di Kepulauan Sapeken Sumenep. Bentuk kegiatan yang dilakukan, yaitu (1) koordinasi dan konsolidasi; (2) pemetaan/kajian potensi budidaya dan aspek sumberdaya manusia (sdm) masyarakat; (3) sosialisasi program dengan pejabat terkait (desa dan dusun), (4) sosialisasi, pelatihan, dan sarana dan prasarana budidaya, penyediaan bibit, dan pelaksanaan budidaya rumput laut; (5) observasi ke daerah budidaya; (6) pendampingan penguatan semangat budidaya; dan (7) sosialisasi dan pencanangan gerakan sadar gizi pelajar kepulauan berbasis sumberdaya laut dan hasil olahannya khususnya rumput laut. Kegiatan pengabdian bermanfaat bagi alternative budidaya berbasis bahari/pesisir yang mendorong peningkatan kesejahteraan masyarakat. Oleh karena itu, perlu kegiatan-kegiatan pengabdian selanjutnya yang terkait pengolahan pasca panen, pemasaran, dan penguatan peran semua pihak, dan pemanfaatan berbagai potensi lainnya di daerah setempat.

\section{Daftar Rujukan}

Adnyani, N. K. S., Sukerti, N. W., \& Wisnawa, I. G. Y. (2014). IbM Kelompok wanita nelayan Tianyar Timur. Singaraja.

Agussalim, A. (2014). Pemberdayaan, upaya meretas kemiskinan masyarakat nelayan. Ambon: BPPP Ambon.

Agustin, T. I., Sulestiani, A., \& Widihartanti, T. (2015). Pemberdayaan masyarakat pesisir melalui pendampingan produksi menuju standarisasi produk di Kelurahan Kedung Cowek-Kenjeran, Surabaya-Jawa Timur. In A. Subianto (Ed.), Prosiding Semiloka Nasional Pemberdayaan Masyarakat Pesisir dalam Rangka Ekonomi Biru (pp. 115-123). Banyuwangi: HAPPI Pusat.

Anonim. (2015a). Profil bisnis usaha mikro, kecil dan menengah (UMKM). Jakarta: Bank Indonesia dan LPPI.

Anonim. (2015b). Tumbuh bersama masyarakat. Jakarta: PT Donggi Senoro.

Bappenas. (2016). Kajian strategi industrialisasi perikanan untuk mendukung pembangunan ekonomi wilayah. (BAPPENAS, Ed.). Jakarta.

Cristianawati. (2017). Tradisi masyarakat nelayan Rawa Pening Kelurahan Bejalen Kecamatan Ambarawa Kabupaten Semarang. Sabda, 12(2), 155-160.

Darmadi, N. M., Ayu, N. M. S., \& Semara, D. G. E. (2016). Ipteks bagi masyarakat nelayan di kelurahan serangan. In Semiinar Nasional Hasil Penelitian dan Pengabdian Kepada Masyarakat (pp. 458-465). Denpasar: UNMAS Denpasar.

DPR RI. (2014). Naskah Akademik dan RUU tentang Perlindungan dan Pemberdayaan Nelayan, Pembudi daya Ikan, dan Petambak Garam, 2013.

Farid, M., Wulanditya, P., \& Puspitaningrum, T. D. K. (2016). Diversifikasi produk olahan kupang sebagai rintisan usaha ibu PKK Desa Bluru Kidul Sidoarjo. In G. Rudiyanto, K. Hutama, D. Asmarandani, S. K. L. Nilotama, S. Sumartono, T. Sekaryati, \& A. U. Nugroho (Eds.), Prosiding Seminar Nasional Pengabdian Kepada Masyarakat (pp. 12-20). Jakarta Barat: Pusat Studi Reka Rancang Visual dan Lingkungan Universitas Trisakti.

Firdaus, M., Indriana, L. F., Dwiono, S. A. P., \& Munandar, H. (2017). Konsep dan proses alih teknologi budidaya terpadu teripang pasir, bandeng dan rumput laut. In S. Y. Nasution, F. Ferianto, S. Maludin, \& P. Yantyo (Eds.), Seminar Nasional Technopreneurship dan Alih Teknologi 2016 (Vol. 2, pp. 51-63). Bogor: Pusat Inovasi-LIPI. 
Hamzah, A. (2015). Pemberdayaan ekonomi nelayan oleh PT. Karya Masyarakat Mandiri Dompet Dhuafa di Desa Tanjung Pasir Kabupaten Tangerang. UIN Syarif Hidayatullah.

Hapsati, Y. T., \& Fuad, A. D. (2017). Manajemen rantai pasokan pada masyarakat nelayan tradisional (Studi kasus pada nelayan Puger Jember). Gulawentah:Jurnal Studi Sosial, 2(2), 67-78.

Hindradjit, H., Rianto, B., \& Arieffiani, D. (2017). Industrialisasi pengolahan ikan tangkap skala rumah tangga untuk meningkatkan ekonomi masyarakat pesisir di Pantai Prigi, Trenggalek. In Seminar Nasional Kelautan XII (pp. 1-12). Surabaya: Fakultas Teknik dan Ilmu Kelautan Universitas Hang Tuah.

Huseini, M. (2007). Masalah dan kebijakan peningkatan produk perikanan untuk pemenuhan gizi masyarakat. In D. P2HP-DKP (Ed.), Seminar Nasional Hari Pangan Sedunia (pp. 1-8). Jakarta: Ditjen P2HP-DKP.

Ibad, S. (2017). Kearifan lokal pemberdayaan masyarakat dalam pengelolaan dan pembangunan sumberdaya perikanan yang berkelanjutan (Studi Kabupaten Situbondo). Samakia: Jurnal Ilmu Perikanan, 8(1), 24-31.

Imaniar, D. (2017). Pemberdayaan masyarakat pesisir (Perempuan nelayan) melalui pemanfaatan pengolahan limbah laut dan cangkang kerang. Jurnal Humaniora, 14(2), 62-66.

Ishak, E., \& Siang, R. D. (2013). Penguatan kapasitas kelompok nelayan wirausaha mandiri melalui transfer teknologi tepat guna. Manajemen IKM, 10(1), 9-16.

Izzaturrahim, Z., Waluti, R., Rahayuwati, R., \& Darmadji, B. N. I. (2015). Peran perempuan dalam pengadaan modal produktif untuk usaha perikanan di kampung nelayan, Tambak Lorok, Semarang. Semarang.

JICA. (2011). Perbaikan mekanisme distribusi studi melalui (Peningkatan penanganan pasca pengembangan pasar ikan panen dan fasilitas pemasaran) di Indonesia. Jakarta.

Karsidi, R. (2002). Pemberdayaan masyarakat petani dan nelayan kecil. In Semiloka Pemberdayaan Masyarakat di Jawa Tengah dalam rangka Pelaksanan Otoda, Badan Pemberdayaan Masyarakat Jateng (pp. 1-11).

Khodijah, K., \& Raza'i, T. S. (2014). Penguatan ekonomi kreatif berbasis sumberdaya desa di Kelurahan Alai Kecamatan Ungar Kabupaten Karimun. Tanjungpinang.

KIARA. (2015). Perempuan nelayan berhak mendapatkan perlindungan dan pemberdayaan dari negara. Jakarta.

Kresnarini, H. I. (2011). Rumput laut dan produk turunannya. Warta Ekspor, 1-20.

Laksamana, H., Ro'is, F., Syahputra, D., Firdausiyah, A. S., \& Reswita, R. (2017). Pemberdayaan ibu rumah tangga nelayan melalui pelatihan diversifikasi produk perikanan dan kelembagaan di Kelurahan Malabero Kota Bengkulu. Jurnal Dharma Raflesia, 15(2), 89-94.

LPPM-UNEJ. (2017). Pengembangan industri kreatif berbasis sumberdaya hayati laut pada komunitas sentra industri kecil di wilayah pesisir pantai. Jember. https://doi.org/10.1016/S00223182(80)80003-3

Masyhuri, M. (2013). Ekonomi syariah dalam etika pemerataan resiko. Jurnal Ekonomi Dan Pembangunan, 21(2), 125-136.

Mutiara, T. K., Wibowotomo, B., Issutarti, I., \& Wahyuni, W. (2018). Diversifikasi pengolahan produk perikanan bagi kelompok nelayan di Kabupaten Trenggalek. Jurnal KARINOV, 1(1), 1-12.

Nahruddin, Z. (2014). Pemberdayaan masyarakat dalam pengelolaan hasil perikanan di Kelurahan 
Sumpang Binangae Kabupaten Barru. Ototritas Jurnal Ilmu Pemerintahan, 4(1), 92-100.

Novianti, N. A. (2017). Usaha berbasis rumah tangga nelayan pada permukiman Suku Bajo di Kelurahan Bajoe Kecamatan Tanete Riattang Timur Kabupaten Bone. Universitas Negeri Makassar.

Nurfadilah, T. (2016). Peranan masyarakat nelayan terhadap peningkatan ekonomi di Desa Kenje Kecamatan Campalagian Kabupaten Polewali Mandar. UIN Alauddin Makassar.

Nurholis, A. (2016). Partisipasi istri nelayan dalam pemanfaatan sumberdaya pesisir (Studi tentang strategi pengentasan kemiskinan keluarga nelayan Desa Margasari Kecamatan Labuhan Maringgai Kabupaten Lampung Timur). Universitas Lampung.

Nurwidodo, N., Rahardjanto, A., Husamah, H., \& Mas'odi, M. (2017). Pendampingan pembuatan aneka olahan rumput laut sebagai upaya penguatan ekonomi masyarakat Kepulauan Sapeken Sumenep. In SENASPRO 2 (pp. 700-714). Malang: DPPM UMM dan UMM Press.

Nurwidodo, N., Rahardjanto, A., Husamah, H., Mas'odi, M., \& Mufrihah, A. (2017). Potentions, obstacels, and strategy in collaboration based developing seaweed cultivation at Sapeken Islands, Sumenep Regency. PROSIDING SEMINAR NASIONAL III TAHUN 2017, 350-360.

Prakoso, J. (2013). Peranan tenaga kerja, modal, dan teknologi terhadap peningkatan pendapatan masyarakat nelayan di Desa Asemdoyong Kecamatan Taman Kabupaten Pemalang. Universitas Negeri Semarang. Retrieved from http://lib.unnes.ac.id/20041/1/7450406043.pdf

Rachmaningtyas, R. M. (2015). Pemberdayaan perempuan nelayan dalam menunjang pendapatan keluarga (Studi pada Kelompok Wanita Tani Aneka Bahari Desa Prigi Kecamatan Watulimo Kabupaten Trenggalek). Universitas Muhammadiyah Malang.

Rahmatullah, R. (2016). Perilaku sosial keagamaan masyarakat nelayan di Kelurahan Baurung Kecamatan Banggae Timur Kabupaten Majene. UIN Alauddin Makassar.

Rosni, R. (2017). Analisis tingkat kesejahteraan masyarakat nelayan di Desa Dhari Kecamatan Talawi Kabupaten Butabara. Jurnal Geografi, 9(1), 53-66.

Rosyid, M. I. (2013). Ekonomi kreatif dalam strategi nafkah masyarakat nelayan. Institut Pertanian Bogor.

Setiawati, C. I., \& Ilma, Z. (2017). Ecopreneurship pada industri perikanan: Bagaimanakah manifestasi ecoinnovation pada fish 'n blues enterprise? Jurnal Manajemen Maranatha, 17(1), 61-70.

Surjanti, J., \& Nuswantara, D. A. (2016). Pemberdayaan sociopreneurship masyarakat nelayan (Studi pada UKM "Crispy Ikan Sunduk" Kabupaten Lamongan). In I. W. Susila, S. Suroto, \& T. Tukiran (Eds.), Prosiding Seminar Nasional Hasil Penelitian dan Pengabdian Kepada Masyarakat. Surabaya: FMIPA dan LPPM UNESA Surabaya.

Sutrisno, E. (2012). Implementasi pengelolaan sumber daya pesisir berbasis pengelolaan wilayah pesisir secara terpadu untuk kesejahteraan nelayan (Studi di perdesaan nelayan Cangkol Kelurahan Lemahwungkuk Kecamatan Lemahwungkuk Kota Cirebon). Jurnal Dinamika Hukum, 14(1), 1-12.

Triadiyatma, A. (2016). Model penyelesaian konflik nelayan berbasis kearifan lokal sebagai modal sosial di Kecamatan Lekok Kabupaten Pasuruan. Universitas Airlangga Surabaya.

Wardhani, R. M., Rekyani, I. P., \& Indayati, I. (2010). Peningkatan pendapatan masyarakat melalui diversivikasi produk olahan ikan (Abon tuna, dendeng lemuru, krupuk rambak tuna). Agritek, 11(2), 54-64.

Wirakusuma, R. M. (2014). Analisis kegiatan ekonomi kreatif di kawasan wisata bahari Pulau Tidung Kepulauan Seribu. Jurnal Manajemen Resort \& Leisure, 11(1), 49-58. 